\title{
Relationship among Building Characteristics, Plant Layout, Landscaping and Student Academic Performance in Kebbi State Secondary Schools, Nigeria
}

\author{
Sani Dantani MANGA, Ph, D \\ Department of Educational Foundations \\ Usmanu Danfodiyo University, Sokoto Nigeria
}

\begin{abstract}
This paper investigated the relationship among building characteristics, plant layout, landscaping and student academic performance in Kebbi State secondary schools, Nigeria. The objectives were to ascertain the characteristics of school plant and if there is any relationship between school plant and student academic performance. The study adopted a descriptive correlational design conducted ex- post facto. Purposive and simple random sampling techniques were used to select 82 boarding schools and 306 teachers out of 1,613. A validated West African Examination Council Results Format; Observation Inventory; and Questionnaire with Cronbach alpha reliability coefficients of $0.83,0.85$ and 0.76 respectively were used to collect data. Rating scales, frequencies, percentages, Analysis of Variance and Multiple Regression analysis at 0.05 alpha level were used in the analysis. It was found that school buildings characteristics, plant layout and landscaping were rated low but were significantly, and highly correlated to student academic performance. It was recommended that school buildings, plant layout and landscaping should be improved to enhance student academic performance
\end{abstract}

Keywords: School Plant, Building Characteristics, Plant Layout, Landscaping, Academ Performance

\section{Introduction}

Education is a powerful instrument for national transformation. But for education to be provided, there must be an enabling environment. To this end, schools are constructed and vested with the responsibility of providing a conducive environment for effective teaching and learning. A good school environment is one that has adequate and suitable buildings in terms of classrooms, libraries, laboratories, workshops, hostels, staff quarters, offices, administrative block, toilets, common norms, dining halls, school fence, furniture, safe playgrounds, water supply, stable electricity power supply, a good layout and beautiful landscaping (Sani, 2007). It is assumed that if a school possesses good buildings, proper layout and landscaping, it will enhance students' academic performance as shown in figure 1 


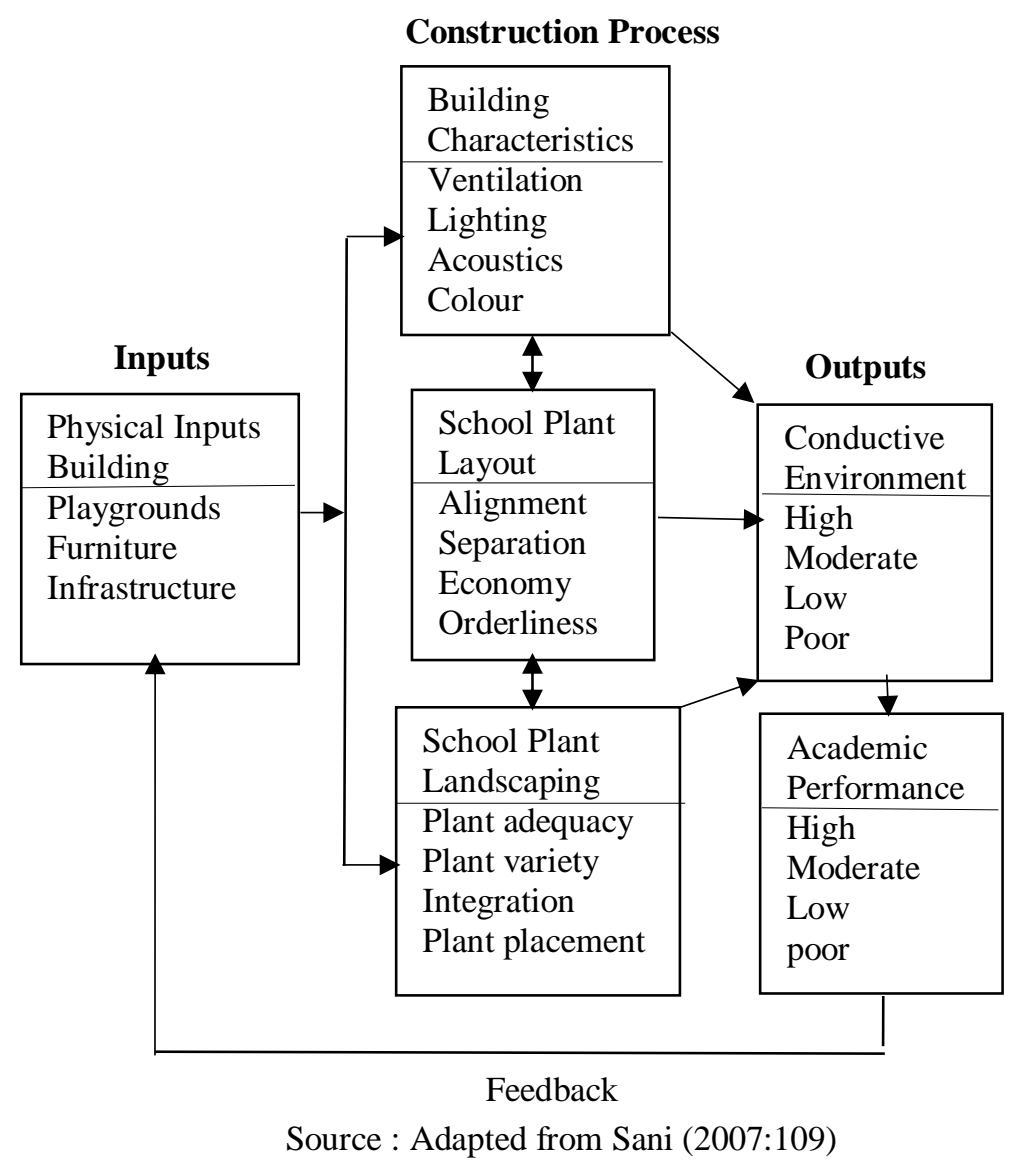

Figure 1 shows that student academic performance is an outcome of the Input - Process - Output equation. It this model, the physical inputs that goes into the educational system among others are school buildings, furniture, playgrounds and infrastructures. The characteristics expected of good school buildings include adequate ventilation, proper lighting, acoustics, modern design, suitable color, spaciousness and durability. Good school plant layout entails orderly arrangement of blocks of buildings, separation of academic areas from noisy playgrounds, workshops, alignment of buildings to sunshine and winds. Landscaping is limited to planting of adequate number of trees and flowers at appropriate places, ensuring that variety of species of trees, flowers, grasses and other types of plants are integrated with the natural vegetation of the locality. Landscaping by planting of trees and flowers is expected to enhance the beauty of the school environment, provide shade to school buildings, provide wind breaks, fruits in due season, medicinal herbs and other benefits that ensure a conducive environment for efficient teaching and learning.

Kebbi state is located in the arid north western Nigeria close to the Sahara desert. The state has 82 Senior Secondary Schools spread across five Education Zones. These school are of different categories which include Science Schools, Technical Colleges, single sexed schools, mixed schools, urban and rural Schools. Every secondary school irrespective of it's type is provided with buildings, playgrounds, furniture and infrastructure for smooth running of academic programmes and co-curricular activities. In spite of those provisions, the academic performance of students in Kebbi State Secondary Schools has been far from satisfactory considering their poor performances in West African School Certificate Examinations (WAEC, 2018). This paper therefore investigated the relationship between school plant and student academic performance with particular focus on quality of school building characteristics, plant layout, landscaping and how they affect student academic performance in Kebbi State Secondary Schools.

\section{Statement of Problem}

Over the last decades, student performance in West African Examinations Council (WAEC) and other ordinary level examinations in Kebbi State has been grossly unsatisfactory. The number of students who fail to get five credits and above including English Language and Mathematics has been fluctuating between 63 - $75 \%$ failure rate (WAEC, 2018). Among the factors attributed to this persistent failure include the inadequacies of existing facilities inherent in school plant construction across the state. There have also been 
complaints by students, teachers, parents and other stakeholders that the quality of school buildings in secondary schools in Kebbi State is not good enough to guarantee a conductive environment for teaching and learning. Some school buildings fall below the standard of quality of ventilation, lighting, spaciousness, colour, acoustics expected in modern buildings. In some schools, buildings appear to be scattered without a properly designed layout, while in most schools, landscaping of the school environment with trees and flowers is largely neglected. But the extent of relationship between school plant and student academic performance in Kebbi State Secondary Schools has not been clearly ascertained to such an extent as to be able to draw authoritative and informed conclusions. This paper therefore sorts to fill this gap by conducting a study to verify a condition of school plant and student academic performance. The main thrust of this study therefore, was to examine the relationship if any among school building characteristics, plant layout, landscaping and student academic performance in secondary schools in Kebbi State.

\section{Objective of the Study}

The objectives of this study were to:

1. assess the level of student academic performance in secondary schools Kebbi State;

2. ascertain the characteristics of school buildings, plant layout and landscaping in secondary schools in Kebbi State; and

3. find out if there is any relationship among school building characteristics, plant layout, landscaping and student academic performance in secondary schools in Kebbi State.

\section{Null Hypothesis}

Ho: There is no significant relationship among building characteristics, plant layout, landscaping and student academic performance in secondary schools in Kebbi state.

\section{Review of Related Literature}

Literature was reviewed on each variable of the study and presented under the following headings:

\section{Schools Building Characteristics}

In modern society the beauty and caliber of school buildings is what visitors use to draw their first impression about the suitability of the school environment for learning and to take decision as to whether to enroll their children in a particular school or not. According to Haese and Goldsmith (2016), a building is simply a structure that has walls, a roof, a door, with or without windows. School buildings are therefore, structures designed and constructed to provide shelter to students, staff, and visitors. For a school building to be considered conducive for teaching and learning it must be spacious, well ventilated, adequately lit, appropriately painted with attractive colours, be of beautiful architectural design and must be in good condition.

A number of studies have been conducted to demonstrate the relationship between building characteristics and student learning. Lackney (2014), investigated the impact of the physical environment of a school on teaching and learning among High School students of Wisconsin, United State of America. In the study, students were divided into two groups. One group was placed in a well-ventilated and well-lit classroom, while the second group of students was placed in a semi-darkened classroom in which windows were shut and the window blinds were drawn. Neither fans nor air conditioners were operated in the darkened classroom. The two groups of students of the same level were taught the same subject for the same duration using the same teaching methods. After the experimental period, the academic performances of the two groups was compared using Teacher Made Tests in Mathematics and Languages. The results of the study show that students in well-lit and well-ventilated classrooms had higher scores in both subjects, which indicated that poor lighting and poor ventilation had direct effect on student comfort, concentration span and by implication, their academic performances.

\section{School Plant Layout}

School layout is very important in ensuring that each school buildings are located at the right places in line with the master plan of a school map. It ensures that the road network, administrative block, staff offices, staff quarters, student hostels, common rooms, toilets classrooms, laboratories, workshops and playgrounds are located at the right places in the school site. Good layout is intended to ease movement of staff, students 
and visitors in a beautiful and well-ordered school environment. According to Stewart (2009), good layout of school plant is crucial in ensuring that:

a. school buildings are properly aligned to climatic elements of sunshine and winds;

b. separation of academic areas requiring quietness are located far from noisy playgrounds and workshops that can interfere with students' concentration on learning tasks;

c. economy of space is maintained for future construction of additional school buildings and infrastructures;

d. orderliness of road network connecting various areas of a school; and

e. arrangement of furniture in school buildings.

This implies that a faulty layout could create interferes in teaching and learning activities, as create unnecessary traffic bottlenecks and well as an ugly and chaotic school environment.

\section{School Plant Landscaping}

Landscaping in this paper is viewed as the systematic planting of trees, flowers, grasses, hedges, parks and gardens, essentially for the purpose of beautification of the school environment. Lowe (2009), investigated the relationship between landscaping and learning in Texas High Schools. The study computed the final year results of 10 schools with good landscaping and those with poor landscaping. He applied t-test and Analysis of Variance to analyze the difference among the schools using 0.05 alpha level. The results of the study show that there was significant difference in the academic performance of students with poor school plant landscaping and the those with good school plant landscaping. With good landscaping performed better than those with poor landscaping. The study concluded that school plant landscaping is very important as it:

a. enhances the beauty of the school environment;

b. attracts students to attend school regularly, which impacts on their performances;

c. provides shade to cool school buildings from the glare of the tropical sun;

d. purifies and provides fresh air in a school environment;

e. provide beautiful parks and gardens for recreation in a school environment

f. provides variety of fruits and vegetables for consumption at all seasons;

g. protects school buildings as trees serve as wind breaks;

h. protect school grounds from soil erosion;

i. serve as fence to demarcate school boundaries and enhance security;

j. Projects a positive image of the school as a public facility; and

k. increases children's prides of their school and symbolizes the communities' heritage and aspirations for the feature.

\section{Research Methodology}

This study used the descriptive correlation research design conducted ex-post facto. The population of the study was made up of all the 82 Boarding Secondary Schools in Kebbi State which were deliberately selected as they provide all facets of school buildings and infrastructures expected in a standard secondary school plant. Simple random sampling technique was used to select 306 teachers out of 1,613 in line with Research Advisors (2006). A combination of researcher designed instruments were used for the study. WAEC Examination Results Formats (WAEC ERF) was used to analyze student academic performance. Observation Inventories on School Building Characteristics, Layout and Landscaping (OISPCLL) were used to assess the existing condition of school facilities. School Plant and Student's Academic Performance Questionnaire (SPSAPQ) was used to elicit responses from participants to the study. Experts in educational management vetted the face, content and construct validity of the instruments. The instruments were pilot tested and Pearson Correlation Coefficient and Cronbach alpha statistics were used to obtain reliability index of $0.85 ; 0.85$ and 0.76 for WAEC Result Format, Observation Inventories and Questionnaire respectively.

All the instruments were rated on five - point scale: $5=$ Very High $(70-100 \%) ; 4=$ High $(60-69 \%) ; 3=$ Moderate (50-59\%); $2=$ Low (40-49\%); and $1=$ Poor (0-39\%). Rating scales and simple percentages were used in answering the research questions, while Analysis of Variance and Multiple Regression Analysis were used to test the hypothesis at 0.05 level of significance. Trained research assistants visited all the sampled schools to collect data and $93 \%$ of the completed copies of the questionnaire were used to analyze the data. 


\section{Results}

Research Question 1: What is the level of student Academic performance in secondary schools in Kebbi State?

Table 1: Kebbi State Students Performance in WAEC, 2013 - 2018

\begin{tabular}{|l|l|l|l|l|l|}
\hline Year & $\begin{array}{l}\text { Number } \\
\text { presented }\end{array}$ & $\begin{array}{l}\text { Number } \\
\text { of 5 credits }\end{array}$ & $\begin{array}{l}\text { Success } \\
\text { Rate }\end{array}$ & $\begin{array}{l}\text { Number } \\
\text { Failed }\end{array}$ & $\begin{array}{l}\text { Failure } \\
\text { Rate }\end{array}$ \\
\hline 2013 & 8200 & 2378 & $29 \%$ & 5822 & $71 \%$ \\
\hline 2014 & 10230 & 2558 & $25 \%$ & 7672 & $75 \%$ \\
\hline 2015 & 12640 & 4677 & $37 \%$ & 7963 & $63 \%$ \\
\hline 2016 & 14500 & 4350 & $30 \%$ & 10150 & $70 \%$ \\
\hline 2017 & 15460 & 5597 & $34 \%$ & 10864 & $66 \%$ \\
\hline 2018 & 17870 & 5540 & $31 \%$ & 12330 & $69 \%$ \\
\hline Total & 79900 & 25100 & & 54800 & \\
\hline Mean & 13317 & 4183 & $31 \%$ & 9133 & $69 \%$ \\
\hline
\end{tabular}

Source: WAEC Results Grade Sheets (2013 - 2018)

Table 1 shows that within the last six years 79,900 students were presented for WAEC out of which only 4183 succeeded in getting five credits and above including English Language and Mathematics. This represented an average a success rate of $31 \%$ and a failure rate $69 \%$. Going by the rating scale adopted, a success rate of $0-39 \%$ is deemed to be poor while a failure rate of $63-75$ indicates a high failure rate. This suggests that the academic performance of students in Kebbi state secondary schools is poor.

Research Question 2: what are the characteristics of school buildings plant layout and landscaping school in secondary schools in Kebbi state?

This research question was answered and presented in table 2.

Table 2: Characteristics of school Buildings, Plant Layout and Landscaping in Secondary Schools in Kebbi State

\begin{tabular}{|c|c|c|c|c|}
\hline $\mathrm{S} / \mathrm{N}$ & Item & Rating & Scale & Percentage \\
\hline 1. & Building Ventilation & Moderate & 3 & $55 \%$ \\
\hline 2. & Lighting of Buildings & Poor & 1 & $25 \%$ \\
\hline 3. & Condition of Buildings & Low & 2 & $45 \%$ \\
\hline 4. & Suitability of Plant Layout & Low & 3 & $50 \%$ \\
\hline 5. & Adequate of landscaping & poor & 1 & $25 \%$ \\
\hline \multicolumn{2}{|r|}{ Suitability of school plant $\bar{X}$} & Low & 2 & $40 \%$ \\
\hline
\end{tabular}

Table 2 shows that the average suitability of school plant for affective teaching and learning was rated Low at the scale of $2=(40 \%)$. This means that the suitability of school facilities was inadequate to ensure good academic performance of students. Suitability of building ventilation was rated Moderate on the scale of $3=$ $(55 \%)$ which signifies moderate suitability. Most classrooms had large windows with cross ventilation but more than $70 \%$ of their ceiling fans were not functional. Suitability of lighting of school buildings was rated Poor on scale of $=1=(25 \%)$, indicating poor lighting as more than $60 \%$ of electric bulbs and fluorescent tubes were not functional. Large windows permit adequate daylight to stream into school building but the buildings cannot be used at night for studies due to lack of electricity as most of the bulbs were either damaged or not available. Condition of school buildings was rated low on the scale of $2=(45 \%)$. This implies that many school buildings had damaged doors, windows, roofs, ceilings, floors and walls. The suitability of school plant layout was rated Moderate on the scale of $3(50 \%)$ which signifies that $50 \%$ of school do not have good layout. The suitability of school landscaping was rated poor on the scale of $1=$ (25\%). This implies that the quality of school plant landscaping in Kebbi State Secondary Schools is generally in adequate and unsuitable to ensure good academic performance among students as many schools do not plant adequate variety of trees, flowers and do not make effort to maintain the flowers. 
Hypothesis One: There is no significant relationship among building characteristics school plant layout, landscaping and student academic performance in secondary school in Kebbi state.

Table 3: Analysis of Variance on Relationship among Building Characteristics, Plant Layout, Landscaping and Student Academic Performance

\begin{tabular}{|l|l|l|l|l|l|}
\hline Model & $\begin{array}{l}\text { Sum of } \\
\text { Squares }\end{array}$ & $\begin{array}{l}\text { Mean } \\
\text { Square }\end{array}$ & $\begin{array}{l}\text { Calculated } \\
\text { F-Value }\end{array}$ & $\begin{array}{l}\text { Critical } \\
\text { F-Value }\end{array}$ & Decision \\
\hline Regression & $.75-89$ & .253 & & & \\
\hline Residual & $7.311 \mathrm{E}-03$ & $3.323 \mathrm{E}-04$ & 76.68 & 3.05 & significant \\
\hline Total & 7.561 & & & & \\
\hline
\end{tabular}

Table 3: Table 3 shows that the Analysis of Variance data yielded 76.68 which is greater than the F-critical value of 3.05 at 0.05 alpha level. The hypothesis which states that there is no significant relationship among school building characteristics, plant layout, landscaping and student academic performance is rejected. This means that school building characteristics, plant layout, landscaping and student academic performance interact individually and collectively to significantly influence one another in Kebbi State secondary schools.

Table 4: Multiple Regression Analysis of Relationship among Student Academic Performance and a Combination of Independent Variables

\begin{tabular}{|l|l|l|l|l|l|l|l|l|}
\hline Variables & B & $\begin{array}{l}\text { Std } \\
\text { Error }\end{array}$ & Beta & T & R & $\begin{array}{c}\text { R } \\
\text { Square }\end{array}$ & Decision \\
\hline Academic & $8.784 \mathrm{E}-04$ & .03 & & .03 & & & & \\
\hline Building & .26 & .13 & .27 & 1.98 & .98 & .99 & Significant \\
\hline Layout & .41 & .10 & .40 & 4.23 & & & \\
\hline Landscaping & .33 & .13 & .33 & 2.55 & & & \\
\hline
\end{tabular}

a. Predictors: Building, Layout, Landscaping

b. Dependent: Academic

Table 4 shows that using school building characteristics, plant layout and landscaping to predict student academic performance, yielded Standardized Regression Weights (B) of .26, .41 and .33 respectively for building characteristics, plant layout and landscaping respectively. These values were significant at $95 \%$ confidence level for prediction of student academic performance. The Beta Weights for school building characteristics, plant layout and landscaping were .27, .40 and .33. This means that school plant layout had the highest correlation to student academic performance. This was followed by school plant landscaping and building characteristic respectively. However, a coefficient of multiple Regression R of .98 at 0.05 alpha level means that the interaction of building characteristics, plant layout, landscaping and student academic performance correlate with one another.

\section{Summary of Findings}

1. Student academic performance in Kebbi State secondary schools was poor within the last six years as $63-75 \%$ of students were unable to score four credit and above in WAEC examinations

2. School buildings were generally unsuitable for effective teaching and learning. Likewise, the layout was mostly inappropriate and landscaping was not properly done in most of the schools.

3. School building characteristics, plant layout and landscaping significantly, positively and highly correlated to student academic performance in Kebbi State secondary schools. This means that suitable building characteristics appropriate layout and proper landscaping enhances student academic performance and vice-versa

\section{Discussion of Findings}

The first finding of this study shows that student academic performance in Kebbi State secondary schools was poor with an average success rate of $31 \%$ and failure rate of $69 \%$ over the last six years. This finding agrees with Iyamu and Aduwa (2014), who noted that some secondary school student in Nigeria, lack 
proficiency in reading, writing and computational skills; problem solving and communication skills, practical and vocational skills and do not exhibit the desired level of knowledge of various subjects that they taught in the curriculum. Uzoka (2000), in a survey he conducted on improving school effectiveness and providing quality education when resources are scares found that Nigerian students perform poorly not only in West African School Certificate Examinations, but also perform woefully in University Matriculation Examinations. The current study similarly found that the suitability of school plant in Kebbi State secondary schools was rated low and therefore, inadequate for effective teaching and learning. This finding also agrees with Durosaro (1998), and Shakeshaft (2014), who maintained that the quality of school plant largely determines the extent of conduciveness of the physical environment in which teaching and learning takes place. According to Amasuomo (2016), a good learning environment has the advantages of fostering desirable behavior, problem solving skills and allows the child to perform leaning tasks with minimum stress.

Result of this study indicates that suitability of building characteristics in terms of ventilation, lighting colour and acoustics were rated low and therefore not satisfactory for enhancing good academic performance. This finding agrees with Lanharm (2015), who worked on relating temperature conditions to student achievement in Virginia Elementary schools. He found that classroom temperatures above $74^{\circ} \mathrm{F}$ adversely reading and mathematical skills. It was also found that there was a significant reduction in reading speed and comprehension when temperatures were between $73.4{ }^{0} \mathrm{~F}$ and $80.6{ }^{0} \mathrm{~F}$. The study concluded that thermal comfort influences task performance. Goroff and Brophy (2015), in their study on electric lighting and daylight in Pennsylvania High Schools, divided their subjects into two groups. They placed one group of students in poorly in classrooms by switching off the lights and blunting day light by drawing the window blinds in the experimental classes so as to create semi darkened classrooms. The other group of students were placed in classrooms that had adequate electrical lighting as well as natural day light streaming into the classrooms. The researchers used pre - test, post - test quasi- experimental design to establish differences in performances of the two groups. The study found that lighting was highly correlated with students' achievement. There was an increase in test scores of students who were placed in well - lit classrooms when compared to those in poorly lit classrooms. The study indicated that student could experience fatigue, poor concentration, eye strain, blurry vision and headaches due to poor lighting.

This study found that suitability of school plant in Kebbi State secondary schools was rated low and that layout had the highest correlation to student academic performance. This is because good layout ensures that classrooms, laboratories and libraries are located far from noisy playgrounds and noise generating technical workshops. The findings agreed with Stewart (2019), who stated that proper layout ensures that furniture is classrooms is well arranged to ease movement of teachers and students to all parts of the classrooms. Good layout of road network helps to define homogeneous activity areas in a school so as to separate quite activity areas from noisy activity areas. Poor layout therefore results in chaotic construction of school buildings and traffic bottlenecks which interferes with teaching and learning.

The finding of this study shows that the quality of landscaping in secondary schools in Kebbi State was poor. This has contributed to some extent in the poor academic performance of students over the years. This is because lack of planting trees exposes school buildings to climatic hazards of being vulnerable to severe damages by violent wind storms which may result in closing the effected school buildings to effect necessary repairs. The period of the closure of classrooms, laboratories, workshops, library or hostels may result in students losing lecture hours or days that may not be replaced. Prolonged period of closure of school buildings can affect students' attendance and by implications, student academic performance for the session. This finding tallies with Lowe (2013), who in his study on the interface between educational facilities and learning climate among secondary school students in Texas, found that the beauty of schools' architectural design and landscaping impact on the learning climate and consequently on students' academic performance. The study found that planting of trees, flowers and gardens was correlated with various measures of students' achievements.

\section{Conclusion}

This study gives credence to the conceptual model in figure 1, which demonstrates that student academic performance is largely determined by the relationship between inputs, processes and the corresponding output. Thus, unsuitable school buildings, improper layout and poor landscaping have contributed significantly to poor academic performance of students in Kebbi State secondary schools. The major focus 
of managerial attention should be on developing strategies towards improving the quality of school plant in order to provide an enabling environment of effective teaching and learning.

\section{Recommendations}

The quality of school plant in secondary schools in Kebbi State should be improved so as to enhance students' academic performance. To this end:

1. Building characteristics should be improved by ensuring that school plant construction is strictly based on correct educational specifications and regulations, which should ensure that school buildings are durable, spacious, well ventilated, have beautiful architectural design, appropriately painted and modernized to fit with current curricular and co - curricular needs.

2. The layout of school facilities should be properly mapped out from the start to end of school plant construction. The school site should have good road network that connect vital areas of the school, separates activity areas and ensures economy of space and orderliness in the arrangement of furniture in classrooms, libraries, laboratories, offices and lecture theatres and halls of residence.

3. Schools should emphasize landscaping by adequately planting a variety trees, flowers and gardens which must be properly arranged and blended with the existing natural vegetation of the environment. This will help to beatify the school environment, attract prospective students to the school, thereby improving enrolment, attendance and student academic performance.

\section{Reference}

[1] Amansuomo. J.O.M (2016). Designing seating arrangement in lecture theatres and classrooms

[2] for effective teachers - students interaction. The Nigeria Teachers Today 7 (1), 116 -1123

[3] Bagudo, A.A. (2004). Critical problems requiring attention: Education in Kebbi State. Paper

[4] presented at the working retreat for Senior Civil Servants of Kebbi State held at Argungu Fishing Festival Hotel, Kebbi State, December 21

[5] Darosaro, A.O. (1998). School plant management practices in Nigeria: Trends, issues and problems. In Olagboye, A.A \& Fadipe, J.O (eds.) Management in Nigeria education project monitoring and school plant maintenance. Ondo: National Institute for Educational Administration and Planning (NIEPA)

[6] Earthman, F.I \& Lemaster, L (2006). Review of research on relationship between buildings,

[7] student's achievement and behavior. Paper presented during the annual meeting of the Council for Education Facility Planning International (CEFPI). Tarpon Springs Florida,Eric document Ed ED416666

[8] Goroff, T.L \& Brophy, J.E (2015). Electric lighting and daylight in schools. Council for Educational Facilities Planning International (CEPPI). Issue track papers. Online: http:www.cefpiiorg/facility planning/htm.

[9] Haese, R.W \& Goldsmith, C, (2016). The living learning physical environment. The Encyclopedia of Education Vol.2, Lee C. Deighton.

[10] Henevaled, W. (2201). Planning and monitoring of primary education in Sub-Sahara Africa. Technical Note. No HRPD. The World Bank

[11] Iyamu, E.O.S \& Aduwa, S.E (2004). Dynamizing the instructional system: An enquiring for effective childhood in Nigeria. Nigerian Journal of Curricular Studies 11 (2), 19-24

[12] Jefffrey, A.S Lackney, R.N (2006). Reading school building like a book: The influence physical setting on learning and literacy. Paper presented at the programme for research and evaluation of public schools (PRESPS) conference, Jacksonville, Mississippi January 18. Online:

http://schoolstudio.engr.wisc.education/readingschool.htm

[13] Lackney, J.A (2014). Educational facilities: The impact and role of the physical environment of school on teaching. University of Wisconsin. Milwaukee Centre for Architectural and urban planning. Research Monograph Series Report P,94. Online: http://www.educationalfacilities.org/rl/ground.maintenance.

[14] Llanharm, J.W (1999). Relating building and classroom condition to student achievement in Virginia. elementary schools. Doctoral dissertation Virginia Polytechnic Institute and State University. 
[15] Lowe, J.M (2013). The interface between educational facilities and learning in elementary schools. Doctoral Dissertation Texas A\&M University.

[16] Research Advisor (2006). Table for determining sample size, level of confidence and margin of error. New York.

[17] Sani, D.M (2207). Relationship among school plant construction, utilization, maintenance and school effectiveness in Kebbi State secondary schools, Nigeria. Doctoral Thesis. University of Ilorin Nigeria.

[18] Shakeshaft, C. (2004). School facilities in Arizona: An examination of the relationship between and among school facilities characteristic and educational outcomes. Online: http://www.sfb..state.az.us/ssfb/doc/find.

[19] Uzoka, N.E (2000). Providing quality education when resources are scarce: strategies for improving school effectiveness. In E.O Fagbamiye \& D.O Durosaro (eds). Education and Productivity in Nigeria. Ilorin: Haytee Press and Publishing Co.

[20] West Africa Examination Council (2018) Result grade sheets of various Colleges/Centers 2013-2018 